\title{
Overexpression of $\alpha$-Internexin Causes Abnormal Neurofilamentous Accumulations and Motor Coordination Deficits in Transgenic Mice
}

\author{
Gee Y. Ching, ${ }^{1}$ Chung-Liang Chien, ${ }^{2}$ Roberto Flores, ${ }^{1}$ and Ronald K. H. Liem ${ }^{1}$ \\ ${ }^{1}$ Departments of Pathology and Anatomy and Cell Biology, Columbia University College of Physicians and Surgeons, New \\ York, New York 10032, and '2Department of Anatomy, National Taiwan University School of Medicine, Taipei, Taiwan 100, \\ Republic of China
}

$\alpha$-Internexin is the first neuronal intermediate filament (IF) protein expressed in postmitotic neurons of the developing nervous system. In the adult, its expression is restricted to mature neurons in the CNS. To study the potential role of $\alpha$-internexin in neurodegeneration, we have generated transgenic mice that overexpress rat $\alpha$-internexin. The total levels of $\alpha$-internexin expressed in the hemizygous and homozygous transgenic mice were $\sim 2$ and $\sim 3$ times the normal level, respectively. Overexpression of $\alpha$-internexin resulted in the formation of cerebellar torpedoes as early as 1 month of age. These torpedoes are abnormal swellings of Purkinje cell axons that are usually seen in neurodegenerative diseases involving the cerebellum. EM studies showed accumulations of high levels of IFs and abnormal organelles in the torpedoes and soma of Purkinje cells, as well as in the large pyramidal neurons of the neocortex and in the ventral anterior and posteromedial nuclei of the thalamus.

$\alpha$-Internexin is a neuronal intermediate filament (IF) protein that is expressed earlier and more abundantly than the neurofilament triplet proteins (NFTPs) throughout the developing CNS (for review, see Fliegner and Liem, 1991). As development continues, the levels of $\alpha$-internexin decrease, whereas those of the NFTPs increase (Kaplan et al., 1990; Fliegner et al., 1994). In adult CNS, $\alpha$-internexin is colocalized with the NFTPs in most axons, but is present at lower levels in large neurons and is found in cerebellar granule cells, which lack the NFTPs (Kaplan et al., 1990). $\alpha$-Internexin can self-assemble and coassemble with each of the NFTPs into filaments, whereas the NFTPs are obligate heteropolymers (Ching and Liem, 1993, 1998; Lee et al., 1993). These properties suggest that $\alpha$-internexin may play a role in stabilizing small-diameter axons and act as a scaffold on which the NFTPs coassemble during development.

Abnormal accumulations of neuronal IFs are pathological hallmarks of many neurodegenerative diseases, such as amyotrophic lateral sclerosis (ALS), Lewy body-type dementias, and Parkin-

\footnotetext{
Received Nov. 9, 1998; revised Jan. 28, 1999; accepted Jan. 28, 1999.

This work was supported by Grant NS15182 from the National Institutes of Health. C.-L. Chien was supported by Grant NSC 88-2314-B-002-119 from National Science Council, Taiwan. We thank Dr. Frank Costantini and Ms. Xiao-lin Liang for generation of transgenic mouse founders, Dr. Mary Bach for helpful advice on the behavioral experiments, Ms. Beth Rosen and Mr. Reilly Coch for their excellent technical assistance, Mr. Adam Nguyen and Ms. Allie Lui for assistance in DNA extraction and tissue sectioning, and Drs. Dongming Sun and Conrad Leung for their help in photographic printing.

Correspondence should be addressed to Dr. Ronald Liem, Department of Pathology, Columbia University College of Physicians and Surgeons, 630 West 168th Street, New York, NY 10032.

Copyright (C) 1999 Society for Neuroscience $\quad 0270-6474 / 99 / 192974-13 \$ 05.00 / 0$
}

Behavioral tests demonstrate that these mice have a deficit in motor coordination as early as 3 months of age, consistent with the morphological neuronal changes. Our data further demonstrate that the neurofilamentous inclusions also lead to progressive loss of neurons in the aged transgenic mice. The motor coordination deficit and the loss of neurons are transgene dosage-dependent. These data yield direct evidence that high levels of misaccumulated neuronal IFs lead to neuronal dysfunction, progressive neurodegeneration, and ultimate loss of neurons. Moreover, the degrees of neuronal dysfunction and degeneration are proportional to the levels of misaccumulated neuronal IFs.

Key words: $\alpha$-internexin; neurofilament; intermediate filament; neurodegeneration; cytoskeleton; transgenic mice; motor deficits son's disease (Munoz et al., 1988; Sasaki et al., 1989; Galloway et al., 1992; Trojanowski and Lee, 1994). Recent transgenic mouse models have shown that overexpression of human NF-H (Cote et al., 1993) or mouse NF-L (Xu et al., 1993) results in axonal swellings and perikaryal accumulation of neuronal IFs in motor neurons, as well as skeletal muscle atrophy. The mice develop signs of muscle weakness and reduced kinetic activity, reminiscent of those found in ALS. Transgenic mice expressing a point mutant of NF-L show neuronal abnormalities resulting in motor neuron death and skeletal muscle atrophy (Lee et al., 1994). NF-H mutations have also been found in sporadic ALS patients (Figlewicz et al., 1994).

Overexpression of wild-type or mutant NFTPs does not always result in ALS-like phenotypes. Transgenic mice that express a $\mathrm{NF}-\mathrm{H} / \beta$-galactosidase fusion protein show perikaryal accumulations of IFs in their motor neurons but do not develop motor neuron degeneration (Eyer and Peterson, 1994). The animals begin to show tremors and selective Purkinje cell loss only at 1 year of age (Tu et al., 1997). Their Purkinje cells contain Lewy body-like inclusions. Transgenic mice that express wild-type human NF-M have normal motor neurons in the spinal cord and exhibit perikaryal accumulations of neurofilaments in other neurons at 12, but not 3, months of age (Vickers et al., 1994). Surprisingly, transgenic mice that overexpress wild-type mouse NF-H or NF-M show neither muscle atrophy nor motor neuron loss, despite prominent axonal swellings and perikaryal neurofilamentous accumulations in motor neurons (Wong et al., 1995; Marszalek et al., 1996).

Thus, overexpressions of different NFTPs have differential 
effects on neurons. Because $\alpha$-internexin differs from the NFTPs in assembly properties and expression pattern, its overexpression may cause a different type of neuropathy and provide additional insights into mechanisms of neuronal dysfunction and neurodegeneration. Our present study shows that subpopulations of CNS neurons appear to be relatively more vulnerable to filamentous misaccumulations induced by $\alpha$-internexin overexpression. Moreover, the transgenic mice show a transgene dosage-dependent deficit in motor coordination.

\section{MATERIALS AND METHODS}

Generation of transgenic mice. To obtain a full-length rat $\alpha$-internexin genomic clone, a $6.4 \mathrm{~kb} B a m \mathrm{HI}-X h o \mathrm{I}$ fragment and a $14.5 \mathrm{~kb}$ XhoI fragment, isolated from the rat $\alpha$-internexin genomic clones $\lambda \alpha \mathrm{G}-1$ and $\lambda \alpha \mathrm{G}-2$ (Ching and Liem, 1991), respectively, were ligated to the BamHISalI digested $\lambda$ DashII phage vector (Stratagene, La Jolla, CA). The resulting genomic clone was designated $\lambda \alpha \mathrm{D}-1$. The transgene construct pSP72N- $\alpha$ ES16K was cloned by ligating the $13 \mathrm{~kb} E c o$ RI fragment from $\lambda \alpha \mathrm{D}-1$ and the $3.5 \mathrm{~kb}$ EcoRI-SalI fragment from $\lambda \alpha \mathrm{G}-2$ together with the EcoRI-SalI digested pSP72N plasmid vector, which was modified from pSP72 (Promega, Madison, WI) by changing the EcoRV cloning site to a NotI site. To obtain the transgene fragment for generation of transgenic mice, the $16.5 \mathrm{~kb}$ NotI-SalI fragment from pSP72N- $\alpha \mathrm{ES} 16 \mathrm{~K}$, consisting of the entire rat $\alpha$-internexin gene with $1.2 \mathrm{~kb}$ of its $5^{\prime}$ flanking sequence and $3.5 \mathrm{~kb}$ of its $3^{\prime}$ flanking sequence, was isolated from agarose gels and purified by glass powder. The resulting $16.5 \mathrm{~kb}$ transgene fragment was further purified by Sephadex G50 spin columns (Boehringer Mannheim, Indianapolis, IN) and prepared at $3 \mu \mathrm{g} / \mathrm{ml}$ in the $10 \mathrm{~mm}$ Tris- $\mathrm{HCl}, \mathrm{pH}$ $7.4,10 \mathrm{~mm} \mathrm{NaCl}$, and $0.2 \mathrm{~mm}$ EDTA buffer. Transgenic mouse founders were generated by microinjecting the transgene fragment into fertilized eggs isolated from B6CBA $F_{1} / \mathbf{J}$ mice (The Jackson Laboratory, Bar Harbor, ME) according to the protocol of Hogan et al. (1986). Two transgenic mouse lines $\alpha 16 \mathrm{~K}-\mathrm{T} 5$ and $\alpha 16 \mathrm{~K}-\mathrm{T} 21$ were established. Hemizygous offspring were obtained by breeding the transgenic mice with B6CBA $F_{1} / J$, and homozygous offspring were obtained by breeding the transgenic mice within each line.

To determine the presence of the transgene in the mice, small tail pieces were cut from the mice, and DNA was extracted from these tails as described (Hogan et al., 1986). Tail DNA was digested with BamHI, separated on $0.8 \%$ agarose gels, and transferred to Zeta-Probe GT membranes (Bio-Rad, Hercules, CA). The $4.4 \mathrm{~kb} \mathrm{BamHI}$ fragment from $\lambda \alpha \mathrm{G}-2$, consisting of the third exon and $3^{\prime}$ flanking sequence of the rat $\alpha$-internexin gene, was used as a hybridization probe to detect the rat but not the mouse $\alpha$-internexin gene. To determine which transgenic mice were homozygous with respect to the transgene, equal amounts of tail DNA from the hemizygous and homozygous mice were used for Southern blot transfer, and a twice stronger rat $\alpha$-internexin hybridization signal on the autoradiogram indicated the homozygosity of the mice. To check the accuracy of the quantities of tail DNA on Southern blots, the membranes were rehybridized with a probe for the endogenous cdk5 gene (Sun et al., 1996), which served as an internal reference. The homozygosity was further confirmed by breeding the mice.

Production of mouse monoclonal antibodies. A $0.8 \mathrm{~kb}$ BglII-Bam HI fragment encoding the $\mathrm{C}$-terminal amino acid residues $340-505$ of rat $\alpha$-internexin and consisting of the SV40 poly A signal was isolated from pRSV- $\alpha$ (Ching and Liem, 1993), blunt-ended with Klenow, and attached to Bam HI linkers (CGCGGATCCGCG). After BamHI digestion, the resulting $0.8 \mathrm{~kb}$ fragment was cloned into the BamHI site on the pET16b vector (Novagen, Madison, WI). The clone, designated $\alpha \mathrm{BB}$, was transformed into the bacterial strain BL21(DE3) for expression. Expression of the $\alpha$-internexin C-terminal peptide, which also contains an N-terminal histidine tag encoded by the pET16b vector, was induced by $0.5 \mathrm{~mm}$ isopropyl- $\beta$-D-thiogalactopyranoside for $4 \mathrm{hr}$. Bacterial cell pellets were suspended in binding buffer $(5 \mathrm{~mm}$ imidazole, $0.5 \mathrm{~mm} \mathrm{NaCl}$, and $20 \mathrm{~mm}$ Tris-HCl, $\mathrm{pH}$ 7.9) and sonicated, and the cell lysate was centrifuged at $20,000 \times g$ for $15 \mathrm{~min}$ at $4^{\circ} \mathrm{C}$. The resulting pellet was resuspended and incubated in binding buffer containing $6 \mathrm{~m}$ urea on ice for $1 \mathrm{hr}$. The cell extract was centrifuged at $39,000 \times g$ for $20 \mathrm{~min}$ at $4^{\circ} \mathrm{C}$. The supernatant was filtered through a $0.45 \mu \mathrm{m}$ membrane and then purified by column chromatography using His-Bind metal chelation resins under denaturing conditions according to the manufacturer's protocol (Novagen). Protein fractions containing the purified $\alpha$-internexin peptide were dialyzed extensively against $10 \mathrm{~mm}$ Tris- $\mathrm{HCl}, \mathrm{pH} 7.5$, at $4^{\circ} \mathrm{C}$. The precipitated protein obtained after dialysis was solubilized by boiling briefly in $10 \mathrm{~mm}$ Tris-HCl, $\mathrm{pH} 7.5$, containing 1\% SDS. For immunization, the purified antigen (100 $\mu \mathrm{g} / \mathrm{immunization})$ was mixed with $0.2 \mathrm{ml}$ saline containing $25 \mu \mathrm{g}$ of monophosphoryl lipid A plus synthetic trehalose dicorynomycolate emulsion (Ribi Immunochem Research), an adjuvant, and injected subcutaneously in two sites on Balb/c mice. Booster injections were given every 3 weeks. Two weeks after the last antigen/ adjuvant injection, another boost was given without adjuvant. Three days later, spleen cells were removed from the immunized mice for fusion with NS-1 myeloma cells, and monoclonal antibodies were produced according to the method of Kohler and Milstein (1976). After immunoblotting and immunohistochemical screening, two monoclonal antibodies, $m A b \alpha 12$ and $m A b \alpha 3 G 10$, were isolated. $m A b \alpha 12$ recognizes only rat $\alpha$-internexin, and $\mathrm{mAb} \alpha 3 \mathrm{G} 10$ reacts with both mouse and rat $\alpha$-internexin.

Antibodies. The following antibodies were obtained commercially (Sigma, St. Louis, MO): mouse monoclonal antibodies to NF-L, NF-M, and NF-H (clones NR4, NN18, and N52, respectively); SMI31 and SMI36, which detect the phosphorylated epitopes on NF-M and NF-H; SMI32, which recognizes the dephosphorylated forms of NF-M and NF-H; and tau-2, which detects both phosphorylated and dephosphorylated forms of tau. Rabbit polyclonal antibody to calbindin $28 \mathrm{kDa}$ was purchased (Swant, Bellinzona, Switzerland). Rabbit polyclonal antibody to GFAP was previously described (Wang et al., 1984).

Western blot analysis. Mouse tissues were homogenized in $10 \mathrm{~mm}$ Tris- $\mathrm{HCl}, \mathrm{pH} 7.5$, and $1 \% \mathrm{SDS}$, boiled for $5 \mathrm{~min}$, and then centrif uged at $13,000 \times g$ for $5 \mathrm{~min}$ to remove insoluble materials. The resulting supernatant contained total proteins extracted from the tissues. Protein concentrations were determined by Bradford assay (Bradford, 1976). Equal amounts of proteins were electrophoresed in 8 or $10 \%$ polyacrylamide-SDS gels (Laemmli, 1970) and then electrotransferred to nitrocellulose filters (Towbin et al., 1979). The filters containing proteins were incubated in PBS containing 5\% bovine serum albumin for $30 \mathrm{~min}$, washed with PBS, and incubated in PBS containing primary antibodies for $1 \mathrm{hr}$. After several washes, they were incubated in PBS containing horseradish peroxidase-conjugated secondary antibodies for $30 \mathrm{~min}$. They were subsequently washed and treated with enhanced chemiluminescence (ECL) reagents (Amersham, Arlington Heights, IL) for $1 \mathrm{~min}$ and exposed to x-ray films. Several exposures of an autoradiogram were used for densitometric analysis.

Immunocytochemistry. Mice were anesthetized and perfused with PBS containing $4 \%$ paraformaldehyde. Frozen cryostat sections of 10-15 $\mu \mathrm{m}$ thickness were prepared from the fixed tissues. The tissue sections were incubated in ice-cold methanol for $10 \mathrm{~min}$, washed, and incubated in PBS containing $5 \%$ normal goat serum for $30 \mathrm{~min}$. They were washed with PBS and then incubated in PBS containing primary antibody for $1 \mathrm{hr}$. After several washes, they were incubated in PBS containing horseradish peroxidase-conjugated secondary antibody for $30 \mathrm{~min}$. They were then washed and treated with PBS containing $0.012 \%$ hydrogen peroxide and $0.5 \mu \mathrm{g} / \mu \mathrm{l}$ diaminobenzidine (DAB). The tissue slides were mounted with Permount (Fisher Scientific, Houston, TX). The DAB/peroxidaseimmunostaining procedure was modified for some primary antibodies: methanol incubation was omitted, $0.1 \%$ Triton X-100 was added to PBS, and tissues were incubated with primary antibody overnight at $4^{\circ} \mathrm{C}$. Indirect immunofluorescence staining using rhodamine- or fluorescentconjugated secondary antibodies was performed as previously described (Ching and Liem, 1993).

Electron microscopy. Mice were anesthetized and perfused with $4 \%$ paraformaldehyde and $2 \%$ glutaraldehyde in $0.1 \mathrm{M}$ cacodylate buffer, $\mathrm{pH}$ 7.4. Tissue blocks were immersed in the same fixative for $24 \mathrm{hr}$ at $4^{\circ} \mathrm{C}$, rinsed in cacodylate buffer, and post-fixed in $1 \%$ osmium tetroxide for 2 hr. After three washes with cacodylate buffer, each sample was dehydrated in a graded series of ethanol and embedded in Epon-Araldite resin. Plastic sections $(1 \mu \mathrm{m})$ were stained with toluidine blue and examined for light microscopy. Ultrathin sections were stained with uranyl acetate and lead citrate and examined with a Hitachi H-7100 electron microscope.

Behavioral tests. Hemizygous, homozygous, and nontransgenic mice of 3 and 6 months of age were tested between 1:00 and 5:00 P.M. in all behavioral experiments. The genotypes of the mice were unknown to the observer at the time of the tests. The apparatus were cleaned thoroughly after each mouse was tested. Statistical significance in performance differences between the genotype groups were calculated using the $F$ test.

The open-field test was used to measure the overall locomotor activities and motor posture patterns (Gerlai et al., 1993). The open-field 
apparatus was a large opaque cage $(12 \times 28 \mathrm{~cm})$ whose bottom was covered with a $4 \times 4 \mathrm{~cm}$ square grid. Mice were habituated to the open-field apparatus twice: $1 \mathrm{hr}$ on the day before testing and $1 \mathrm{hr}$ on the test day. Individual mice were placed in the center of the cage, and their movements were quantified for $20 \mathrm{~min}$. The following behaviors were recorded: locomotion score (number of squares crossed on the floor grid), frequencies (number of times in a test period) of rearing and defecation, and duration (as a percentage of the test period) of grooming.

The rotorod test was used to measure motor coordination and balance (Janicke et al., 1983; Luo et al., 1996). The rotorod apparatus, Rotarod MECO, was purchased from Columbus Instruments and consists of a 1.75 inch rod with a rubber outer texture for grip. The rotorod speed was electronically gauged. The mice were habituated on the rotorod apparatus before testing by placing them on the rod for $1 \mathrm{~min}$ at the rotating speed of 2 revolutions per minute $(\mathrm{rpm})$. The habituation was repeated after the mice were given a 1 min rest. After habituation, the mice were given a $5 \mathrm{~min}$ rest and tested at a rotating speed of $10 \mathrm{rpm}$. Timing started when the mice were placed on the rotating rod and stopped when the mice fell off from the rotating rod or after 3 min elapsed, whichever came first. After a 3 min rest, the test was repeated. The retention times on the rotorod were averaged for each mouse.

To compare the performance between the 4.5-month-old hemizygous mice and their nontransgenic littermates on the rotorod, the mice were tested at the rotating speed of $17 \mathrm{rpm}$ as described above, except that timing stopped when the mice fell off from the rotating rod or after $4 \mathrm{~min}$ elapsed, whichever came first.

Quantitations of Purkinje cells. For each transgenic mouse genotype examined at 12 and 18 months of age, three or four pairs of transgenic/ nontransgenic mice per age group were used for quantitation of Purkinje cells present in cerebellum. A complete set of $10-\mu \mathrm{m}$-thick paraffinembedded brain sections was prepared from each mouse, and every fifteenth section was picked and stained with cresyl violet. Comparable sections from the transgenic mice and their nontransgenic littermates were selected for cell counting. The presence of cell nucleus was used as a criterion for scoring the number of Purkinje cells present within each selected section. For each mouse pair, the total number of Purkinje cells from the set of the transgenic mouse sections was calculated as a percentage of that of the nontransgenic littermate. The final value of the Purkinje cell number determined for each transgenic mouse genotype group at an age point was the average of these calculated percentages obtained from quantitation of three or four pairs of transgenic/nontransgenic mice.

\section{RESULTS}

\section{Neuron-specific overexpression of $\alpha$-internexin in transgenic mice}

We previously isolated two genomic clones containing partial sequences of the rat $\alpha$-internexin gene (Ching and Liem, 1991). To generate transgenic mice overexpressing $\alpha$-internexin, we used the two genomic clones to construct a transgene, which consists of the entire rat $\alpha$-internexin gene with $1.2 \mathrm{~kb}$ of $5^{\prime}$ flanking sequence and $3.5 \mathrm{~kb}$ of $3^{\prime}$ flanking sequence. The resulting $16.5 \mathrm{~kb}$ transgene fragment was microinjected into the pronuclei of fertilized mouse eggs. Two transgenic mouse lines, $\alpha 16 \mathrm{~K}-\mathrm{T} 5$ and $\alpha 16 \mathrm{~K}-\mathrm{T} 21$, were established. These two lines expressed and transmitted the transgene in a Mendelian manner. To distinguish the expression of the transgenic product, rat $\alpha$-internexin, from that of the endogenous mouse protein, we prepared a monoclonal antibody that is specific for the rat protein. Rat and mouse $\alpha$-internexin share high homology in their primary sequence but differ in a short stretch of amino acids at their C-terminus (Chien and Liem, 1994). We therefore used a bacterially produced peptide consisting of the $\mathrm{C}$-terminal region of rat $\alpha$-internexin as an immunogen and generated a number of monoclonal antibodies. One of these monoclonal antibodies, $\mathrm{mAb} \alpha 12$, recognizes rat but not mouse $\alpha$-internexin. Another monoclonal antibody, mAb $\alpha 3 \mathrm{G} 10$, recognizes both rat and mouse $\alpha$-internexin (see Figs. 1 and 2 for antibody specificity).

Western blot and densitometric analyses showed that wild-type rat $\alpha$-internexin was expressed in the brains (with cerebella removed), cerebella, and spinal cords of the 3-month-old hemizygous mice from $\alpha 16 \mathrm{~K}-\mathrm{T} 5$ and $\alpha 16 \mathrm{~K}-\mathrm{T} 21$ at approximately the same levels as the endogenous mouse $\alpha$-internexin (Fig. $1 A$ ). This twofold increase in the total levels of $\alpha$-internexin had no effect on the expression levels of the NFTPs in the transgenic mice (Fig. $1 A)$. Immunoblotting and immunocytochemical analyses performed on various tissues such as brain, spinal cord, heart, lung, liver, spleen, kidney, stomach, intestines, and muscle showed that expression of rat $\alpha$-internexin in the transgenic mice was restricted to neurons. Immunocytochemical examination of the transgenic mouse neural tissues also revealed that rat $\alpha$-internexin was present in the same regions where the endogenous mouse $\alpha$-internexin is expressed. Furthermore, the expression patterns of the transgene in the two transgenic mouse lines were found to be identical.

To increase the levels of $\alpha$-internexin further, we bred the hemizygous mice within each transgenic mouse line to obtain transgenic mice that are homozygous with respect to the transgene. Western blot and densitometric analyses showed that the total $\alpha$-internexin levels increase to approximately threefold in the homozygous mice as expected (Fig. $1 B$ ), whereas the levels of NFTPs remain unaltered (data not shown).

\section{Abnormal accumulation of neuronal intermediate filaments and formation of cerebellar torpedoes}

Immunocytochemical analyses showed that both the hemizygous and homozygous mice of $\alpha 16 \mathrm{~K}-\mathrm{T} 5$ and $\alpha 16 \mathrm{~K}-\mathrm{T} 21$ contain abnormally intense anti- $\alpha$-internexin antibody staining in the perikarya of specific groups of neurons in the cerebellum, neocortex, and thalamus. The abnormal immunostaining patterns, seen as early as 1 month of age, appeared similar between the hemizygous and homozygous mice, except that the neuronal perikarya were more strongly stained by the $\alpha$-internexin antibody in the homozygotes. Furthermore, ultrastructural studies showed that there was a greater accumulation of intermediate filaments in the neuronal perikarya of the homozygous mice than in those of the hemizygous mice. Immunocytochemical and ultrastructural analyses revealed that the two mouse lines have similar morphological changes in the CNS (also see below).

In the cerebella of 4.5-month-old hemizygous and homozygous mice of $\alpha 16 \mathrm{~K}-\mathrm{T} 5$ and $\alpha 16 \mathrm{~K}-\mathrm{T} 21$ (Fig. $2 A, B$ ), the perikarya of Purkinje cells were heavily stained by the anti- $\alpha$-internexin antibodies $\mathrm{mAb} \alpha 12$, which specifically recognizes rat $\alpha$-internexin, and $\mathrm{mAb} \alpha 3 \mathrm{G} 10$, which reacts with both rat and mouse $\alpha$-internexin. Immunostaining of the cerebellar white matter indicated colocalization of rat and mouse $\alpha$-internexin within the nerve fibers. Numerous fusiform swellings of the proximal portions of Purkinje cell axons labeled by the antibodies to $\alpha$-internexin (Fig. $2 A, B$ ) were found in the granular layer. These fusiform swellings, called torpedoes, are usually seen in neurodegenerative diseases involving the cerebellum and in normal aging (Duchen, 1984; Hirano, 1988). These torpedoes were also labeled by an antibody to calbindin, which serves as a protein marker for Purkinje cells (data not shown). The torpedoes were observed in the hemizygous and homozygous mice at as early as 1 month of age. In the nontransgenic littermates, Purkinje cell perikarya were not stained by the anti- $\alpha$-internexin antibody, and no torpedoes were observed (Fig. 2C). The torpedoes and perikarya of Purkinje cells of the transgenic mice were also stained by the antibodies to the NFTPs (Fig. $5 E, F$ ). This result is consistent with the ability of $\alpha$-internexin to coassemble with the NFTPs into 


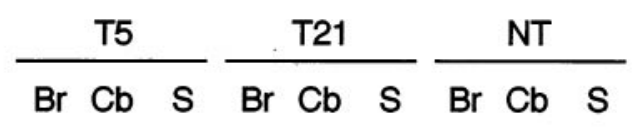

A

(a)

\begin{abstract}
Rat $\alpha$
\end{abstract}
(b)

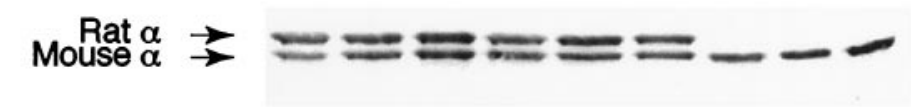

(c)

NF-L

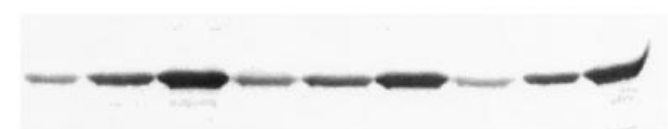

(d)

NF-M

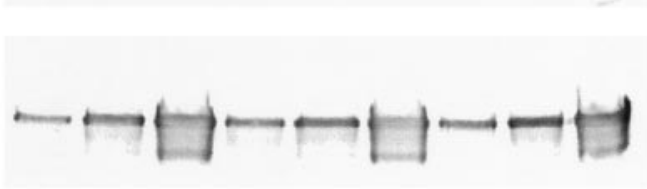

(e)

NF-H

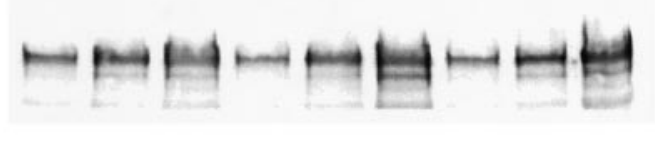

B
Figure 1. Western blot analysis of $\alpha$-internexin and NFTPs in transgenic mice. $A$, Total cellular proteins extracted from the brains (with cerebella removed) $(\mathrm{Br})$, cerebella $(\mathrm{Cb})$, and spinal cords $(S)$ of 3 -month-old $\alpha 16 \mathrm{~K}-\mathrm{T} 5$ and $\alpha 16 \mathrm{~K}-\mathrm{T} 21$ hemizygous mice and nontransgenic (NT) littermates were separated by SDS-polyacrylamide gel electrophoresis and electrotransferred to nitrocellulose filters. The filters were immunostained with anti- $\alpha$-internexin antibodies $\mathrm{mAb} \alpha 12(a)$ or mAb $\alpha 3 \mathrm{G} 10(b)$; monoclonal antibodies to NF-L $(c)$, NF-M $(d)$, or NF-H $(e)$. Several different exposures of the autoradiograms were used for densitometric analysis: rat and mouse $\alpha$-internexin were expressed at approximately the same levels, except that the level of rat $\alpha$-internexin in the $\mathrm{Br}$ fraction of $\alpha 16 \mathrm{~K}-\mathrm{T} 5$ is $\sim 1.2$ times that of mouse $\alpha$-internexin; the endogenous levels of NFTPs remain unaltered. $B$, Western blots containing total cellular proteins extracted from the brains (with cerebella removed) $(B r)$, cerebella $(\mathrm{Cb})$, and spinal cords $(S)$ of 3-month-old $\alpha 16 \mathrm{~K}$-T5 and $\alpha 16 \mathrm{~K}-\mathrm{T} 21$ homozygous mice and nontransgenic $(N T)$ littermates were immunostained with anti- $\alpha$ internexin antibody $\mathrm{mAb} \alpha 3 \mathrm{G} 10$. Densitometric analysis showed that rat $\alpha$-internexin was expressed at $\sim 2$ times the level of mouse $\alpha$-internexin in the homozygotes, except that the level of rat $\alpha$-internexin is $\sim 2.5$ times that of mouse $\alpha$-internexin in the $\mathrm{Br}$ fraction of $\alpha 16 \mathrm{~K}-\mathrm{T} 5$. filaments (Ching and Liem, 1993, 1998) and the colocalization of $\alpha$-internexin with the NFTPs in the CNS axons (Kaplan et al., 1990). Thus, the immunocytochemical data showed that overexpression of $\alpha$-internexin in the transgenic mice caused the formation of torpedoes and abnormal accumulation of neuronal intermediate filaments (composed of $\alpha$-internexin and NFTPs) in the perikarya of Purkinje cells.

Ultrastructural analysis of the abnormal Purkinje cells by electron microscopy revealed a swirl of closely packed, randomly oriented neuronal intermediate filaments in the cytoplasm (Fig. $3 A$ ). The nucleus was eccentrically localized, and many cellular organelles were pushed to the periphery by the masses of neuronal intermediate filaments (data not shown). Some of the mitochondria that were trapped within the neurofilamentous masses looked abnormal or smaller than normal and often associated with the smooth endoplasmic reticulum (Fig. $3 A$ ). The bulk of the torpedo consists of masses of closely packed, randomly oriented neuronal intermediate filaments and aggregates of organelles (Fig. 4A,B). Some mitochondria and smooth endoplasmic reticulum looked abnormal, and their membranes appeared to be continuous with each other. These features are typical of torpedoes found in human neurodegenerative diseases (Mann et al., 1980). The Purkinje cell axon distal to the Purkinje cell soma and torpedo contains high levels of neuronal intermediate filaments (Fig. 4C). Despite the perikaryal accumulation of neuronal intermediate filaments and the formation of torpedoes, no significant loss of neurons was observed at 4.5 months of age.
Immunocytochemical examination of the neocortex of 4.5month-old hemizygous and homozygous mice of the two transgenic lines also showed the presence of filamentous inclusions in the perikarya of large pyramidal neurons in layers III and V that were intensely stained by the $\alpha$-internexin antibodies, mAb $\alpha 12$ and mAb $\alpha 3 \mathrm{G} 10$ (Fig. $5 A$ ), as well as by the antibodies to the NFTPs (Fig. 5C). Although these filamentous inclusions have a neurofibrillary tangle-like appearance, they were not stained by an anti-tau antibody that recognizes both the phosphorylated and nonphosphorylated forms of tau (data not shown). Because tau is the major constituent of the paired helical filaments (Kondo et al., 1988; Goedert et al., 1989; Brion et al., 1991), the absence of tau immunostaining indicated that the filamentous inclusions in the perikarya of these neurons differ from the neurofibrillary tangles of Alzheimer's disease. Similar perikaryal staining was also detected in the ventral anterior nucleus and ventral posteromedial nucleus of the transgenic mouse thalamus (Fig. 5B). Examination of these abnormal neurons in the neocortex and thalamus by electron microscopy revealed the presence of massive levels of closely packed, randomly oriented neuronal intermediate filaments in the cytoplasm and an eccentrically displaced nucleus (Fig. 3B). Cellular organelles such as some of the mitochondria and smooth endoplasmic reticulum that were trapped within the neuronal intermediate filaments looked abnormal and often aggregated, but those that were squeezed to the periphery by the neuronal intermediate filaments appeared normal (Fig. $3 B$ ). In 

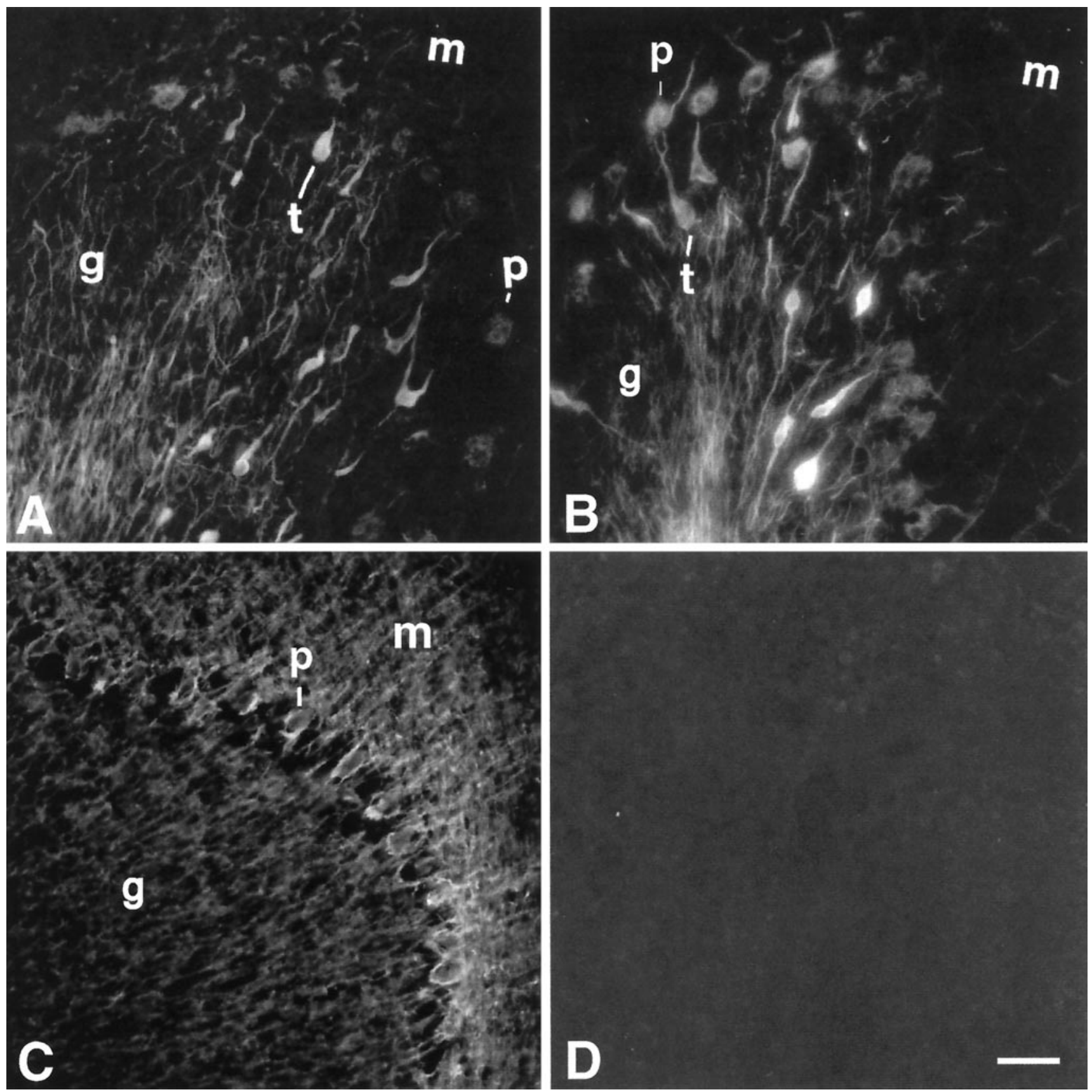

Figure 2. Indirect immunofluorescence staining of cerebella from 4.5-month-old transgenic and nontransgenic mice with anti- $\alpha$-internexin antibodies. Sagittal sections $(15 \mu \mathrm{m})$ of cerebella from $\alpha 16 \mathrm{k}-\mathrm{T} 5(A)$ and $\alpha 16 \mathrm{k}-\mathrm{T} 21(B)$ hemizygous mice and nontransgenic littermates $(C, D)$ were stained with anti- $\alpha$-internexin antibodies. $A$ and $C$ were stained with mAb $\alpha 3 \mathrm{G} 10$, which detects both mouse and rat $\alpha$-internexin. $B$ and $D$ were stained with mAb $\alpha 12$, which specifically recognizes rat $\alpha$-internexin. Perikaryal immunostaining of Purkinje cells and torpedoes were detected in the transgenic mice, but not in their nontransgenic littermates. $p$, Purkinje cell; $t$, torpedo; $m$, molecular layer; $g$, granular layer. Scale bar, $45 \mu \mathrm{m}$.

contrast to the Purkinje cells, prominent swellings of proximal axons were not seen in these neurons although higher neurofilament density was found in the axons. Furthermore, no obvious neuronal loss was observed.

Abnormal phosphorylation of NF-M and NF-H in perikaryal neurofilamentous inclusions is often a hallmark of human neurodegenerative diseases (Schmidt et al., 1987; Kato and Hirano, 1990; Nakazato et al., 1990; Sobue et al., 1990). To determine whether NF-H and NF-M in the perikarya of the cerebellar Purkinje cells, neocortical pyramidal neurons, and thalamic neurons described above were phosphorylated, three monoclonal antibodies, SMI31, SMI32, and SMI36, were used for immunocytochemical staining. SMI31 and SMI36 detect phosphorylated epitopes, whereas SMI32 recognizes only nonphosphorylated forms of NF-M and NF-H. The results showed that the perikarya of the neurons containing neurofilamentous inclusions were stained by SMI32, but not by SMI31 and SMI36, indicating that the NF-M and NF-H accumulated in the neuronal perikarya were not phosphorylated (Fig. $5 C-F$ ). In contrast, the cerebellar torpedoes were stained by all three antibodies, demonstrating the presence of both phosphorylated and nonphosphorylated forms of NF-M and NF-H in the torpedoes (Fig. $5 E, F$ ). 

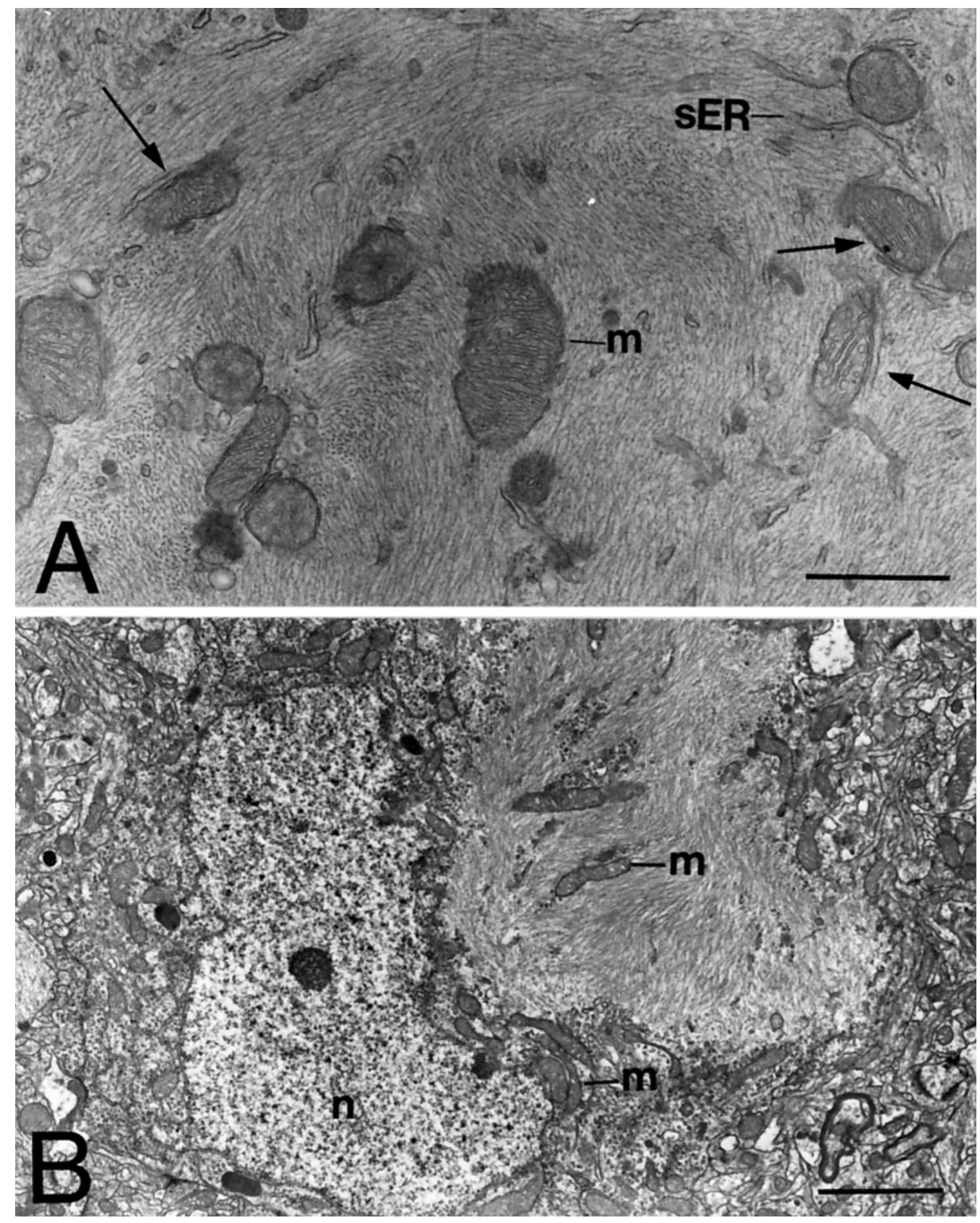

Figure 3. Ultrastructural analysis of Purkinje cells and neocortical pyramidal neurons from 4.5 -month-old transgenic mice. $A$, Ultrathin sections of cerebellum from an $\alpha 16 \mathrm{k}-\mathrm{T} 5$ homozygous mouse examined by electron microscopy revealed accumulation of high levels of intermediate filaments in the soma of a Purkinje cell. Lying within the neurofilamentous masses are aggregates of mitochondria and sER, some of which appear to associate with each other (arrows). Although the external membranes of these mitochondria appear to be continuous with sER, some other mitochondria look normal. $B$, Electron micrograph showed massive accumulation of intermediate filaments in the soma of a neocortical pyramidal neuron from a 4.5-month-old $\alpha 16 \mathrm{k}-\mathrm{T5}$ homozygous mouse. Note that the nucleus is eccentrically localized, and many cellular organelles such as mitochondria are peripherally displaced. Some mitochondria trapped within the masses of neuronal intermediate filaments often aggregate and appear abnormal. The neuronal intermediate filaments in $A$ and $B$ are highly packed and randomly oriented. $m$, Mitochondria; $s E R$, smooth endoplasmic reticulum; $n$, nucleus. Scale bars: $A, 0.75 \mu \mathrm{m} ; B, 2.0 \mu \mathrm{m}$.

Examination of the spinal cords of the transgenic mice did not reveal any perikaryal accumulation of neuronal intermediate filaments in motor neurons or axonal swellings, although expression of the transgene increases the levels of $\alpha$-internexin in the spinal cord to $\sim 3$ times the normal levels in the homozygotes. Consistent with the normal morphology observed in the spinal cord, no skeletal muscle atrophy was found in the transgenic mice (data not shown).

\section{Deficit in motor coordination of transgenic mice}

Neither the hemizygous nor homozygous mice of the $\alpha 16 \mathrm{~K}-\mathrm{T} 5$ and $\alpha 16 \mathrm{~K}-\mathrm{T} 21$ lines showed tremors or any other overt symptoms of disorders. They also appeared to reproduce normally, similar to their nontransgenic littermates. To assess any possible deficits in motor performance of the transgenic mice resulting from the observed neuronal pathology, we subjected the mice to a battery 

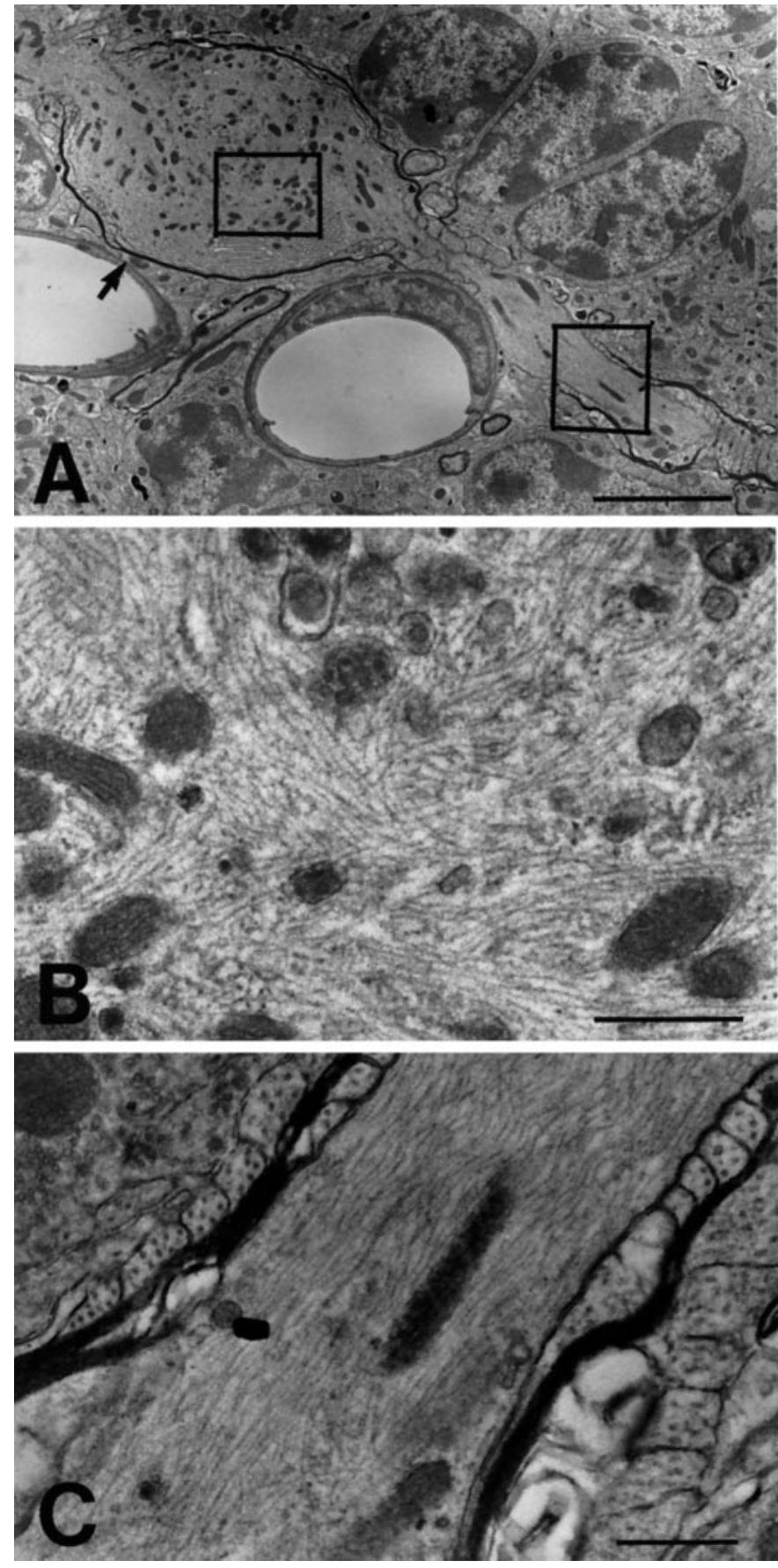

Figure 4. Ultrastructural analysis of cerebellar torpedo in transgenic mice. $A$, Electron micrograph of the cerebellum from a 4.5 -month-old $\alpha 16 \mathrm{k}-\mathrm{T} 21$ homozygous mouse showed the presence of a torpedo (arrow) in the granular layer. $B$, High-magnification micrograph of the torpedo $(A$, squared area) revealed the presence of closely packed, randomly oriented neuronal intermediate filaments and aggregates of organelles. $C$, Highmagnification micrograph of the Purkinje cell axon ( $A$, squared area) distal to the torpedo revealed the presence of high levels of neuronal intermediate filaments. Scale bars: $A, 4.0 \mu \mathrm{m} ; B, 0.4 \mu \mathrm{m} ; C, 0.5 \mu \mathrm{m}$.

of behavioral tests. Two age groups ( 3 and 6 months) of homozygous, hemizygous, and nontransgenic mice were tested, and their performances were compared. The mice within each age group were weight-matched. Because the two transgenic mouse lines showed identical expression patterns, neuronal pathologies and motor performances in preliminary behavioral tests, they were pooled into the same groups for behavioral analysis.

Analysis by the open-field test revealed no significant differences ( $p>0.05, F$ test) in locomotion, grooming, and rearing between the transgenic and nontransgenic mice (Table 1). Although the frequency of defecation was found significantly smaller in the 3-month-old homozygous transgenic mice $(p<$ $0.05)$ compared with that of the nontransgenic mice, it was not significant $(p>0.05)$ among the 6-month-old mice. Taken together, these results indicate that the overall locomotor activity and gross motor-posture patterns of the transgenic mice were indistinguishable from those of the nontransgenic mice.

The mice were subsequently tested for motor coordination and balance on a rotorod. The results showed significant differences ( $p<0.001, F$ test $)$ in the retention times on the rotorod between genotype groups (Fig. 6). The 3- and 6-month-old homozygous mice performed more poorly than the age-matched hemizygous and nontransgenic groups. There were no significant differences $(p>0.05)$ in performance between the hemizygous and nontransgenic mice at a rotating speed of $10 \mathrm{rpm}$ (Fig. 6A). To determine whether the $\alpha$-internexin-overexpressing hemizygous mice show impairment in motor coordination on a rotorod at a higher speed, new groups of 4.5-month-old hemizygous and nontransgenic mice were tested at a rotating speed of $17 \mathrm{rpm}$. At this speed, the retention times of the hemizygous mice were much shorter than those of the age-matched nontransgenic mice (Fig. $6 B)$. These results suggest that both the hemizygous and homozygous mice of $\alpha 16 \mathrm{~K}-\mathrm{T} 5$ and $\alpha 16 \mathrm{~K}-\mathrm{T} 21$ are impaired in the ability to perform a complex pattern of movements involving high demands in motor coordination and balance. Furthermore, the poorer performance of the homozygous mice, compared with the hemizygous mice, indicates that the motor impairment is transgene dosage-dependent.

\section{Neuronal degeneration in transgenic mice}

Examination of the brains from the older hemizygous and homozygous mice (12-18 months of age) of $\alpha 16 \mathrm{~K}-\mathrm{T} 5$ and $\alpha 16 \mathrm{~K}-\mathrm{T} 21$ at the light and electron microscopic levels revealed neuronal degeneration that is progressive with increasing age of the mice (Figs. 7, 8, Table 2). Loss of neurons was seen in the neocortex, thalamus, and cerebellum of aged transgenic mice (Fig. 7). Ultrastructural analysis of the brains from 13-month-old transgenic mice showed degenerating and degenerated processes in the molecular layer (Fig. 8A) as well as degenerating torpedoes and degenerated axons in the granular layer (Fig. $8 B$ ). Degenerated and degenerating axons and processes were also found in the neocortex (Fig. 8C) and the thalamus (data not shown). In all three brain regions, microglia were often detected at the neuronal degeneration sites (Fig. 8C). High levels of neuronal intermediate filaments were still present in the perikarya of Purkinje cells, neocortical pyramidal neurons, and thalamic neurons. In contrast, degenerated processes and axons were very rarely found in the nontransgenic littermates. These data showed that misaccumulation of high levels of neuronal intermediate filaments ultimately led to neuronal degeneration in the older transgenic mice.

Examination of the cerebella from the hemizygous and homozygous transgenic mice at 12-18 months of age revealed progressive loss of Purkinje cells (Fig. $7 A-D$ ). Quantitative analysis of Purkinje cell numbers showed that at 12 months of age, the hemizygous and homozygous mice had a decrease of 16.6 and $37.4 \%$, respectively, in the Purkinje cell population (Table 2). By 

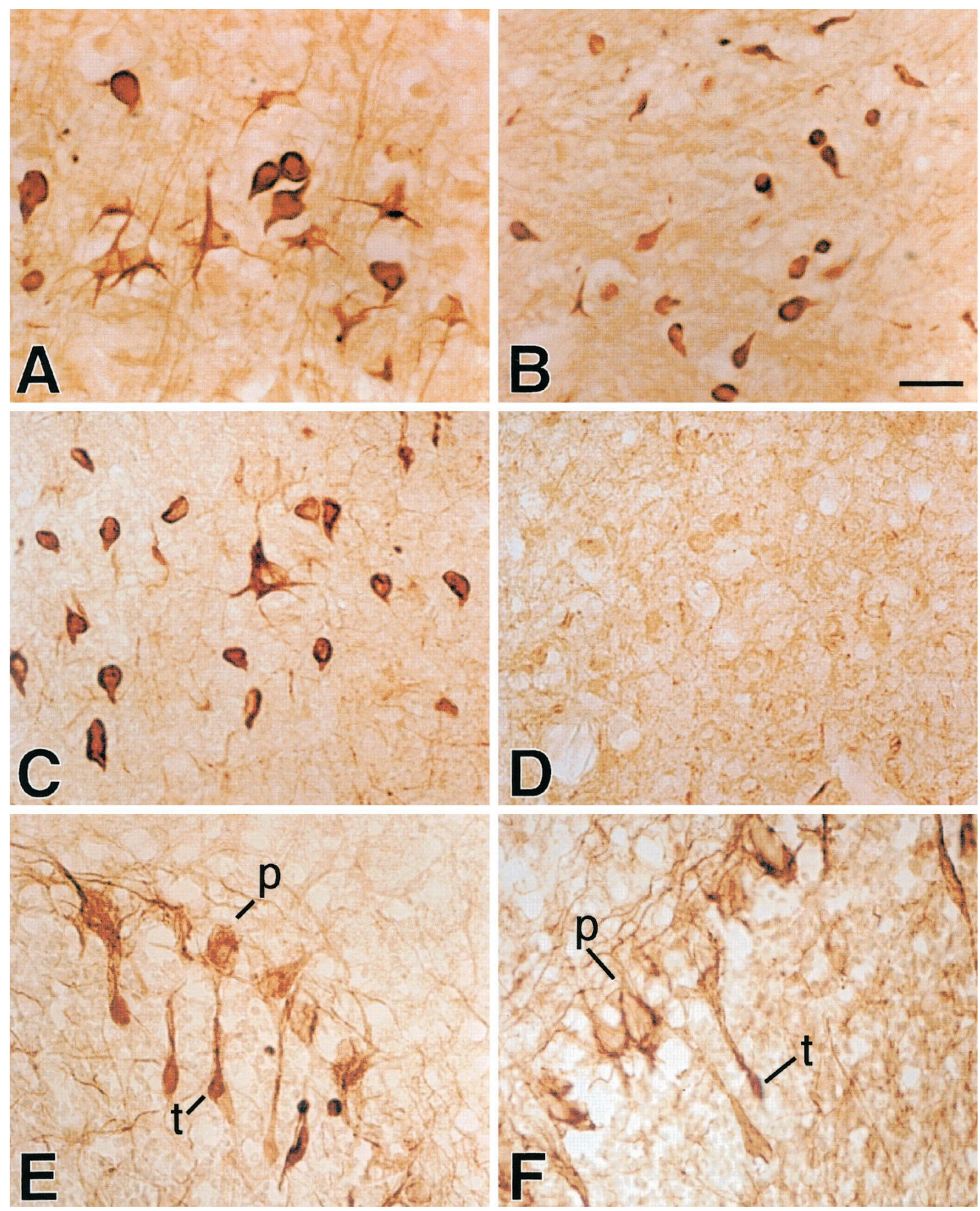

Figure 5. Immunocytochemical analysis of brains from 4.5-month-old transgenic mice. Sagittal sections of neocortex $(A, C, D)$, thalamus $(B)$, and cerebellum $(E, F)$ from $\alpha 16 \mathrm{k}-\mathrm{T} 5$ homozygous mice were stained with antibodies mAb $\alpha 3 \mathrm{G} 10$, which reacts with both rat and mouse $\alpha$-internexin $(A, B)$, SMI32, which detects only the nonphosphorylated forms of NF-M and NF-H $(C, E)$, or SMI36, which recognizes phosphorylated epitopes on NF-M and NF-H $(D, F)$. Perikaryal immunostainings were observed with mAb $\alpha 3$ G10 and SMI32, but not with SMI36. In contrast, torpedoes were stained by both SMI32 and SMI36. $p$, Purkinje cell; $t$, torpedo. Scale bar, $35 \mu \mathrm{m}$.

18 months of age, there is a further decrease in the number of Purkinje cells, with a 60.6 and $71.5 \%$ loss in the hemizygous and homozygous mice, respectively. Overall, the extent of Purkinje cell loss was greater in the homozygous mice than in the hemi- zygous mice. Taken together, these data demonstrated that misaccumulation of high levels of neuronal intermediate filaments in Purkinje cells ultimately led to the degeneration and death of these neurons. 
Table 1. Motor and posture patterns of transgenic and nontransgenic mice measured in open-field test

\begin{tabular}{|c|c|c|c|c|c|c|}
\hline & \multicolumn{6}{|l|}{ Mice } \\
\hline & \multicolumn{3}{|l|}{3 months of age } & \multicolumn{3}{|l|}{6 months of age } \\
\hline & Nontransgenic & Hemizygous & Homozygous & Nontransgenic & Hemizygous & Homozygous \\
\hline Locomotion score & $333 \pm 121$ & $331 \pm 99$ & $317 \pm 102$ & $217 \pm 90$ & $271 \pm 134$ & $236 \pm 101$ \\
\hline Rearing frequency & $64.7 \pm 28.5$ & $57.1 \pm 24.5$ & $62.1 \pm 21.2$ & $37.8 \pm 15.2$ & $40.3 \pm 24.0$ & $43.4 \pm 25.2$ \\
\hline Grooming time (\%) & $5.62 \pm 3.65$ & $4.78 \pm 3.25$ & $5.38 \pm 4.11$ & $7.28 \pm 5.34$ & $7.67 \pm 5.29$ & $5.30 \pm 3.79$ \\
\hline Defecation frequency & $5.6 \pm 1.6$ & $4.9 \pm 1.7$ & $4.1 \pm 1.2^{*}$ & $5.4 \pm 2.2$ & $4.2 \pm 2.5$ & $5.5 \pm 2.4$ \\
\hline
\end{tabular}

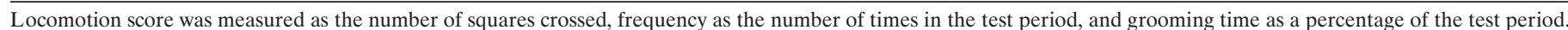
Values given are means \pm SD.

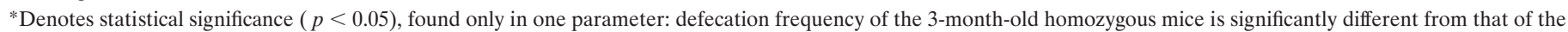
nontransgenic mice of the same age.

\section{A}

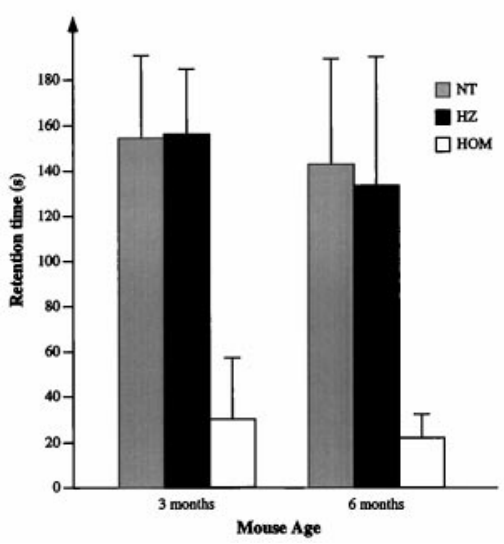

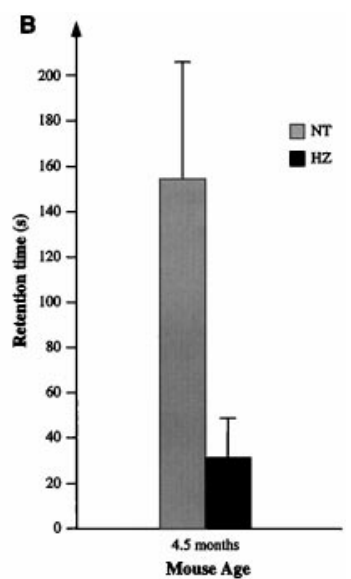

Figure 6. Comparison of performance in rotorod test between transgenic and nontransgenic mice. $A, \alpha$-Internexin-overexpressing hemizygous $(H Z)$ and homozygous $(H O M)$ mice of 3 and 6 months of age and their age-matched nontransgenic $(N T)$ littermates $(n=10$ each group) were tested, and their retention times (in seconds) on the rotorod at a speed of $10 \mathrm{rpm}$ were compared. The $\alpha$-internexin-overexpressing homozygous mice, but not the hemizygous mice, performed poorly compared with their nontransgenic littermates (3-month-old mice, $F_{(2,27)}=$ 56.7, $p<0.001$; 6-month-old mice, $F_{(2,27)}=27.5, p<0.001$. $B$, $\alpha$-Internexin-overexpressing hemizygous $(H Z)$ mice of 4.5 months of age and their age-matched nontransgenic $(N T)$ littermates $(n=15$ each group) were tested at a speed of $17 \mathrm{rpm}$ on the rotorod, and their retention times (in seconds) were compared. There is a significant difference $(p<0.001 ; F$ test) in the retention times between the hemizygous mice and their nontransgenic littermates.

\section{DISCUSSION}

Our studies demonstrate that overexpression of $\alpha$-internexin induces the formation of cerebellar torpedoes and abnormal accumulations of neuronal intermediate filaments (composed of $\alpha$-internexin and the NFTPs) in the brains of the $\alpha 16 \mathrm{~K}-\mathrm{T} 5$ and $\alpha 16 \mathrm{~K}-\mathrm{T} 21$ hemizygous and homozygous mice as early as 1 month of age. Furthermore, these mice exhibit a transgene dosagedependent deficit in motor coordination as early as 3 months of age. Because there is no obvious loss of neurons at this age, the observation of a deficit in the motor coordination of the transgenic mice indicates that the functions of the affected neurons are compromised because of misaccumulations of high levels of neuronal intermediate filaments. The mechanism by which the accumulations of neuronal intermediate filaments occur in these animals is not clear. It is possible that the system responsible for transporting neuronal intermediate filaments to the axons is overloaded by excessive amounts of $\alpha$-internexin in the transgenic mice and as a result, $\alpha$-internexin as well as the NFTPs accumulate in the neuronal perikarya and swollen axons.

Unlike some of the transgenic mice that express wild-type or mutant NFTPs (Cote et al., 1993; Xu et al., 1993; Eyer and Peterson, 1994; Lee et al., 1994; Wong et al., 1995; Marszalek et al., 1996), the $\alpha 16 \mathrm{~K}-\mathrm{T} 5$ and $\alpha 16 \mathrm{~K}-\mathrm{T} 21$ transgenic mice did not show any axonal swellings and perikaryal accumulation of neuronal intermediate filaments in the motor neurons of the spinal cord, although the expression levels of $\alpha$-internexin increased in these neurons. Consistent with this result, they also did not develop any skeletal muscle atrophy or ALS-like phenotype. Because $\alpha$-internexin is normally expressed at much lower levels than the NFTPs in the motor neurons of the spinal cord (Chiu et al., 1989; Kaplan et al., 1990; Fliegner et al., 1994), the increased levels of $\alpha$-internexin may still be insufficient to cause misaccumulation of neuronal intermediate filaments in motor neurons.

In contrast, morphological analyses of the brains of the $\alpha 16 \mathrm{~K}-\mathrm{T} 5$ and $\alpha 16 \mathrm{~K}-\mathrm{T} 21$ mice revealed different groups of neurons that are susceptible to the overexpression of $\alpha$-internexin. Abnormal perikaryal accumulations of neuronal intermediate filaments were detected in the Purkinje cells of the cerebellum, the large pyramidal neurons in layers III and V of the neocortex, and the ventral anterior nucleus and ventral posteromedial nucleus of the thalamus. Prominent swellings of the Purkinje cell axons also occurred, resulting in the presence of numerous torpedoes in the granular layer of the cerebellum. Thus, Purkinje cells appear to be the most affected by the overexpression of $\alpha$-internexin. Although these abnormal morphological changes were detected as early as 1 month of age, prominent loss of the affected neurons was seen mainly in the aged ( $\geq 12$ months) transgenic mice, indicating a remarkable degree of tolerance of the neurons for massive misaccumulation of neuronal intermediate filaments. This neuronal tolerance may contribute in part to the slow process of neuronal degeneration and hence the gradual progression of neurodegenerative diseases with neurofilamentous inclusions.

Consistent with the slow process of neuronal degeneration in neurodegenerative diseases, the neurodegeneration and ultimate loss of neurons observed in the old $\alpha$-internexin-overexpressing transgenic mice (12-18 months of age) are progressive with increasing mouse age. By 18 months of age, prominent loss of Purkinje cells $(\geq 60 \%)$ was observed in both hemizygous and homozygous mice. Furthermore, the extent of neuron loss is proportional to the levels of misaccumulated neuronal intermediate filaments, as indicated by the greater loss of Purkinje cells in the homozygous mice compared with the hemizygous mice. Thus, our data yield direct evidence that misaccumulation of high levels 

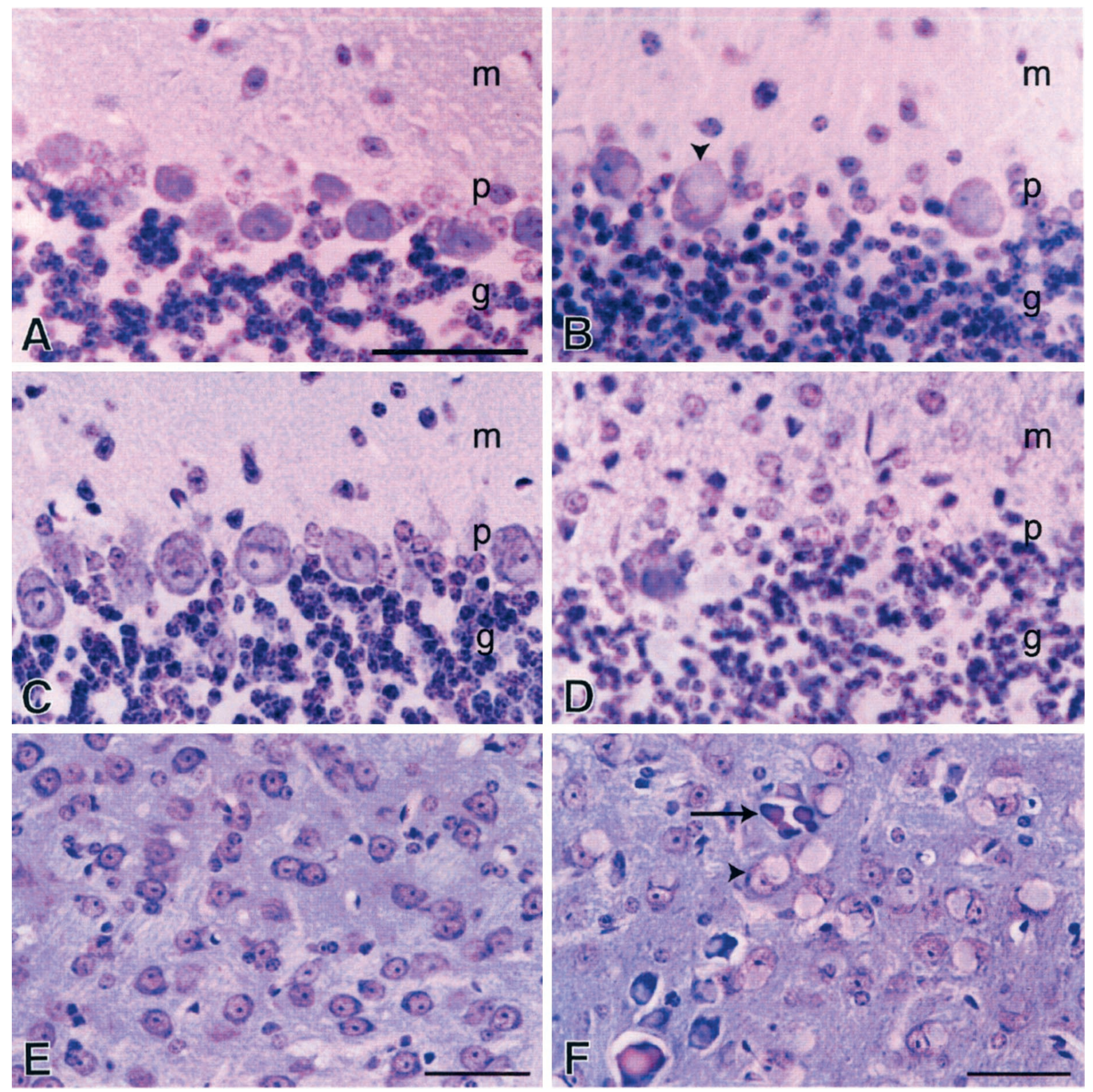

Figure 7. Neuronal degeneration in aged transgenic mice. Sagittal paraffin-embedded sections $(10 \mu \mathrm{m})$ were stained with cresyl violet and examined by light microscopy. $A-D$, Examination of the cerebella from 12-month-old nontransgenic $(A)$ and homozygous $(B)$ mice, and 18 -month-old nontransgenic $(C)$ and homozygous $(D)$ mice revealed progressive loss of Purkinje cells as the transgenic mice aged $(C, D)$. Arrowhead in $B$ shows a Purkinje cell containing neurofilamentous inclusion. $m$, Molecular layer; $p$, Purkinje cell; $g$, granular layers. $E, F$, Examination of the thalamus from 18-month-old nontransgenic $(E)$ and homozygous mice $(F)$ showed the presence of degenerated neurons (arrow) and neurons containing neurofilamentous inclusions (arrowhead) in the transgenic mice. Scale bars: $A-D, 50 \mu \mathrm{m} ; E, F, 50 \mu \mathrm{m}$.

of neuronal intermediate filaments arising from overexpression of $\alpha$-internexin can cause progressive neurodegeneration and neuron death.

The transgene dosage-dependent motor coordination deficits observed in the $\alpha$-internexin-overexpressing transgenic mice demonstrate that high levels of misaccumulated neuronal intermediate filaments can compromise the normal functions of neurons containing filamentous inclusions. The degree of this neuronal dysf unction is proportional to the levels of misaccumulated neuronal intermediate filaments, as shown by the poorer performance of the homozygous mice, compared with the hemizygous mice, in the rotorod test. Moreover, this neuronal dysfunction occurs before the neuronal degeneration and loss seen in the transgenic mice. The resulting deficit in the motor coordination of the transgenic mice is consistent with the observed morphological neuronal changes. Motor coordination requires the normal operation of a number of neural structures, which also include the motor cortex, thalamus, and cerebellum (Thach et al., 1992; 

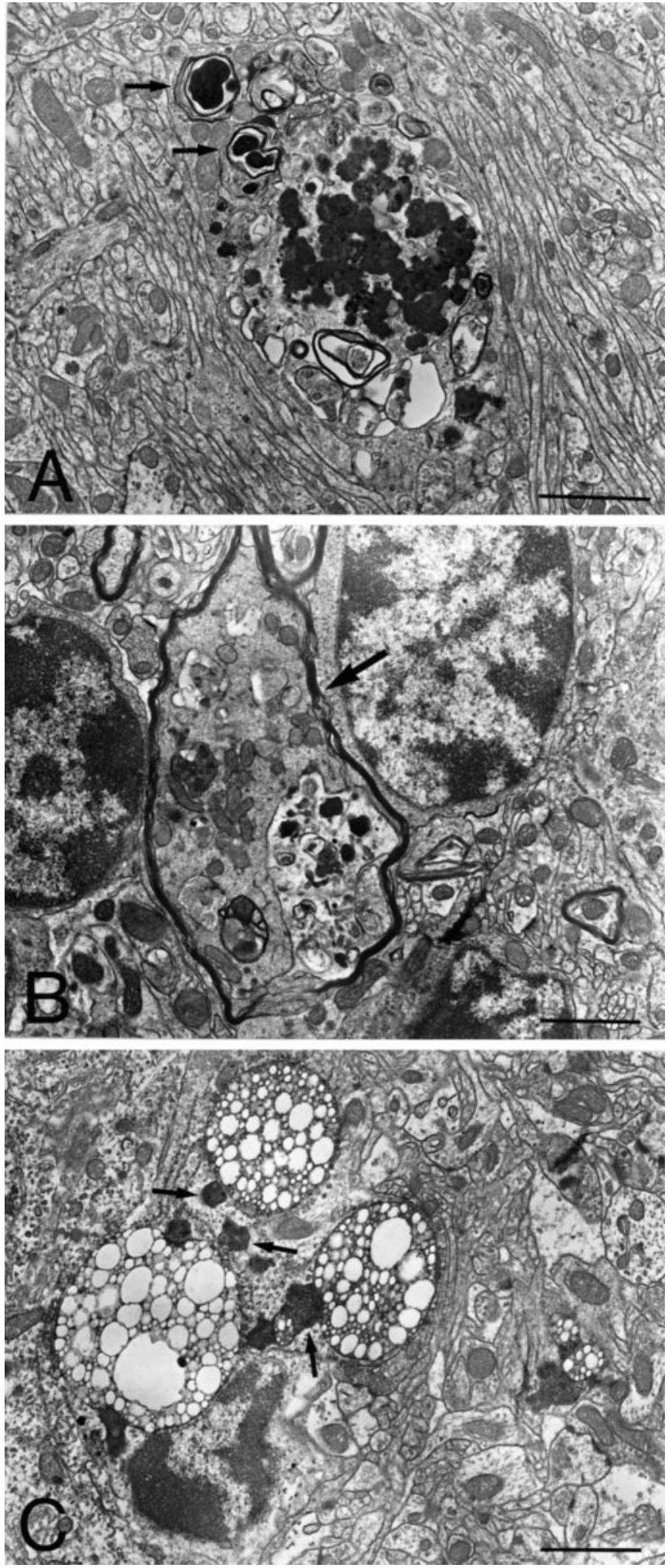

Figure 8. Ultrastructural analysis of the cerebellum and neocortex from 13-month-old transgenic mice. Electron micrographs of the cerebellum $(A, B)$ and neocortex $(C)$ from 13-month-old $\alpha 16 \mathrm{k}$-T5 homozygous mice revealed degenerated processes (arrows) in the molecular layer $(A)$ and a degenerating torpedo (arrow) in the granular layer $(B)$ of the cerebellum, and degenerated processes (arrows) and nearby microglial cells in the neocortex $(C)$. Scale bars: $A, 2.0 \mu \mathrm{m} ; B, 1.5 \mu \mathrm{m} ; C, 1.5 \mu \mathrm{m}$.
Table 2. Quantitation of Purkinje cell numbers in transgenic mice overexpressing $\alpha$-internexin

\begin{tabular}{lll} 
Genotype & Age (months) & Number of Purkinje cells present $(\%)$ \\
\hline Hemizygous & 12 & $83.4 \pm 2.1$ \\
& 18 & $39.4 \pm 4.4$ \\
Homozygous & 12 & $62.6 \pm 3.7$ \\
& 18 & $28.5 \pm 5.1$
\end{tabular}

*Numbers of Purkinje cells present in the transgenic mice are expressed as percentages of those in the nontransgenic littermates.

Values given are means \pm SD (from quantitation of three or four pairs of transgenic/ nontransgenic mice in each group).

Llinas and Welsh, 1993; Ivry, 1997). These neural structures together control and regulate movement specification and initiation. The cerebellum, in particular, is widely believed to play a crucial role in coordinating and modulating unskilled and skilled movements and is implicated in regulating the temporal patterns of movement. It also directs its output to the cerebral cortex and thalamus. Purkinje cells, the neurons most affected by the overexpression of $\alpha$-internexin, send their axons to the deep cerebellar nuclei, the major output pathway from the cerebellum. The abnormal pyramidal neurons containing neurofilamentous inclusions are located in the premotor and motor areas of the neocortex. Thus, it is not surprising that the transgenic mice with the morphological neuronal changes in the cerebellum, neocortex, and thalamus are impaired in motor coordination.

Misaccumulation of high levels of neuronal intermediate filaments may induce neuronal dysfunction and degeneration by at least two mechanisms. The findings of some abnormal cellular organelles (such as the mitochondria and smooth endoplasmic reticulum) entrapped within the perikaryal neurofilamentous inclusions and an increase in the number of these abnormal organelles in the older $\alpha$-internexin-overexpressing transgenic mice suggest that the cellular metabolism may be perturbed because of the organelle damages and a shortage of normal organelles required for neuronal function and viability, ultimately resulting in neuronal dysfunction and degeneration. Moreover, the neuronal intermediate filaments present in the cerebellar torpedoes and perikarya of the affected neurons in the $\alpha$-internexin-overexpressing transgenic mice are randomly oriented. Excessive accumulation of these disorganized neurofilamentous cytoskeletons may cause defects in axonal transport of neurofilaments and other cellular components essential for axonal maintenance. It has previously been shown that overexpression of human NF-H in transgenic mice impairs the axonal transport of NFTPs and cellular organelles (Collard et al., 1995). Retardation in the slow axonal transport of cytoskeletal elements during aging (McQuarrie et al., 1989) may further compound the impairment of axonal transport caused by the abnormal accumulation of neuronal intermediate filaments, thereby accelerating axonal degeneration in older transgenic mice.

The presence of phosphorylated NF-M and NF-H in perikaryal neurofilamentous inclusions is often a pathological hallmark of many neurodegenerative diseases (Schmidt et al., 1987; Kato and Hirano, 1990; Nakazato et al., 1990; Sobue et al., 1990). This abnormal presence of phosphorylated NF-M and $\mathrm{NF}-\mathrm{H}$ in neuronal perikarya has also been observed in some of the transgenic mice overexpressing wild-type or mutant NFTPs (Xu et al., 1993; Eyer and Peterson, 1994; Lee et al., 1994; Tu et al., 1997). Study of neurofilamentous aggregates induced in cultured neurons suggests that perikaryal accumulation of neuronal 
intermediate filaments precedes the aberrant phosphorylation of NF-H in the cell body (Straube-West et al., 1996). In contrast, phosphorylated NF-M and NF-H were not detected in the perikarya of the neurons containing the neurofilamentous inclusions in the $\alpha$-internexin-overexpressing transgenic mice, but were found in the axons where they are normally confined (Sternberger and Sternberger, 1983; Carden et al., 1987). It seems that the massive misaccumulation of neuronal intermediate filaments caused by the overexpression of $\alpha$-internexin does not induce any inappropriate activation of kinases or inactivation of phosphatases in the affected neurons that could lead to the aberrant phosphorylation of NF-M and NF-H in the perikarya.

In contrast to the NFTPs, little is known about the potential involvement of $\alpha$-internexin in the pathogenesis of neurodegenerative diseases. The $\alpha$-internexin-overexpressing transgenic mice differ from the NFTP-overexpressing transgenic mice in neuronal pathologies, as well as in the phenotype induced by misaccumulation of massive neuronal intermediate filaments, and hence provide an additional system for elucidating mechanisms of neuronal dysfunction and degeneration. The data obtained from the studies of the $\alpha$-internexin-overexpressing transgenic mice yield direct evidence that high levels of misaccumulated neuronal intermediate filaments lead to neuronal dysfunction, progressive neurodegeneration, and ultimate loss of neurons. The use of both hemizygous and homozygous mice allows demonstration of a direct correlation of the levels of misaccumulated neuronal intermediate filaments to the degree of neuronal dysfunction and degeneration observed. Furthermore, these transgenic mice show neuronal dysfunction preceding neuronal loss, a pattern characteristic of some of the human neurodegenerative diseases containing neurofilamentous inclusions. In view of these data, the transgenic mouse model presented here also provides some initial insights into the role that $\alpha$-internexin may play in the pathogenesis of human neurodegenerative diseases.

\section{REFERENCES}

Bradford MM (1976) A rapid and sensitive method for the quantitation of microgram quantities of protein utilizing the principle of protein-dye binding. Anal Biochem 72:248-254.

Brion JP, Hanger DP, Bruce MT, Couck AM, Flament-Durand J, Anderton BH (1991) Tau in Alzheimer neurofibrillary tangles. N- and C-terminal regions are differentially associated with paired helical filaments and the location of a putative abnormal phosphorylation site. Biochem J 273:127-133.

Carden MJ, Trojanowski JQ, Schlaepfer WW, Lee VM (1987) Twostage expression of neurofilament polypeptides during rat neurogenesis with early establishment of adult phosphorylation patterns. J Neurosci 7:3489-3504.

Chien CL, Liem RK (1994) Characterization of the mouse gene encoding the neuronal intermediate filament protein $\alpha$-internexin. Gene 149:289-292.

Ching GY, Liem RK (1991) Structure of the gene for the neuronal intermediate filament protein $\alpha$-internexin and functional analysis of its promoter. J Biol Chem 266:19459-19468.

Ching GY, Liem RK (1993) Assembly of type IV neuronal intermediate filaments in nonneuronal cells in the absence of preexisting cytoplasmic intermediate filaments. J Cell Biol 122:1323-1335.

Ching GY, Liem RK (1998) Roles of head and tail domains in $\alpha$-internexin's self-assembly and coassembly with the neurofilament triplet proteins. J Cell Sci 111:321-333.

Chiu FC, Barnes EA, Das K, Haley J, Socolow P, Macaluso FP, Fant J (1989) Characterization of a novel $66 \mathrm{kd}$ subunit of mammalian neurofilaments. Neuron 2:1435-1445.

Collard JF, Cote F, Julien JP (1995) Defective axonal transport in a transgenic mouse model of amyotrophic lateral sclerosis. Nature 375:61-64.

Cote F, Collard JF, Julien JP (1993) Progressive neuronopathy in trans- genic mice expressing the human neurofilament heavy gene: a mouse model of amyotrophic lateral sclerosis. Cell 73:35-46.

Duchen L (1984) General pathology of neurons and neuroglia. In: Greenfield's neuropathology, Ed 4 (Hume A, Corsellis J, Duchen L, eds), pp 1-52. London: Edward-Arnold.

Eyer J, Peterson A (1994) Neurofilament-deficient axons and perikaryal aggregates in viable transgenic mice expressing a neurofilament- $\beta$ galactosidase fusion protein. Neuron 12:389-405.

Figlewicz DA, Krizus A, Martinoli MG, Meininger V, Dib M, Rouleau GA, Julien JP (1994) Variants of the heavy neurofilament subunit are associated with the development of amyotrophic lateral sclerosis. Hum Mol Genet 3:1757-1761.

Fliegner KH, Liem RK (1991) Cellular and molecular biology of neuronal intermediate filaments. Int Rev Cytol 131:109-167.

Fliegner KH, Kaplan MP, Wood TL, Pintar JE, Liem RK (1994) Expression of the gene for the neuronal intermediate filament protein $\alpha$-internexin coincides with the onset of neuronal differentiation in the developing rat nervous system. J Comp Neurol 342:161-173.

Galloway PG, Mulvihill P, Perry G (1992) Filaments of Lewy bodies contain insoluble cytoskeletal elements. Am J Pathol 140:809-822.

Gerlai R, Friend W, Becker L, O'Hanlon D, Marks A, Roder J (1993) Female transgenic mice carrying multiple copies of the human gene for S100 $\beta$ are hyperactive. Behav Brain Res 55:51-59.

Goedert M, Spillantini MG, Jakes R, Rutherford D, Crowther RA (1989) Multiple isoforms of human microtubule-associated protein tau: sequences and localization in neurofibrillary tangles of Alzheimer's disease. Neuron 3:519-526.

Hirano A (1988) Color atlas of pathology of the nervous system, Ed 2. New York: Igaku-shoin.

Hogan B, Costantini F, Lacy E (1986) Manipulation of the mouse embryo: a laboratory manual. Cold Spring Harbor: Cold Spring Harbor Laboratory.

Ivry R (1997) Cerebellar timing systems. Int Rev Neurobiol 41:555-573.

Janicke B, Schulze G, Coper H (1983) Motor performance achievements in rats of different ages. Exp Gerontol 18:393-407.

Kaplan MP, Chin SS, Fliegner KH, Liem RK (1990) $\alpha$-internexin, a novel neuronal intermediate filament protein, precedes the low molecular weight neurofilament protein (NF-L) in the developing rat brain. J Neurosci 10:2735-2748.

Kato S, Hirano A (1990) Ubiquitin and phosphorylated neurofilament epitopes in ballooned neurons of the extraocular muscle nuclei in a case of Werdnig-Hoffmann disease. Acta Neuropathol (Berl) 80:334-337.

Kohler G, Milstein C (1976) Derivation of specific antibody-producing tissue culture and tumor lines by cell fusion. Eur J Immunol 6:511-519.

Kondo J, Honda T, Mori H, Hamada Y, Miura R, Ogawara M, Ihara, Y (1988) The carboxyl third of tau is tightly bound to paired helical filaments. Neuron 1:827-834.

Laemmli UK (1970) Cleavage of structural proteins during the assembly of the head of bacteriophage T4. Nature 227:680-685.

Lee MK, Xu Z, Wong PC, Cleveland DW (1993) Neurofilaments are obligate heteropolymers in vivo. J Cell Biol 122:1337-1350.

Lee MK, Marszalek JR, Cleveland DW (1994) A mutant neurofilament subunit causes massive, selective motor neuron death: implications for the pathogenesis of human motor neuron disease. Neuron 13:975-988.

Llinas R, Welsh JP (1993) On the cerebellum and motor learning. Curr Opin Neurobiol 3:958-965.

Luo L, Hensch TK, Ackerman L, Barbel S, Jan LY, Jan YN (1996) Differential effects of the Rac GTPase on Purkinje cell axons and dendritic trunks and spines. Nature 379:837-840.

Mann DM, Stamp JE, Yates PO, Bannister CM (1980) The fine structure of the axonal torpedo in Purkinje cells of the human cerebellum. Neurol Res 1:369-378.

Marszalek JR, Williamson TL, Lee MK, Xu Z, Hoffman PN, Becher MW, Crawford TO, Cleveland DW (1996) Neurofilament subunit NF-H modulates axonal diameter by selectively slowing neurofilament transport. J Cell Biol 135:711-724.

McQuarrie IG, Brady ST, Lasek RJ (1989) Retardation in the slow axonal transport of cytoskeletal elements during maturation and aging. Neurobiol Aging 10:359-365.

Munoz DG, Greene C, Perl DP, Selkoe DJ (1988) Accumulation of phosphorylated neurofilaments in anterior horn motoneurons of amyotrophic lateral sclerosis patients. J Neuropathol Exp Neurol 47:9-18. 
Nakazato Y, Hirato J, Ishida Y, Hoshi S, Hasegawa M, Fukuda T (1990) Swollen cortical neurons in Creutzfeldt-Jakob disease contain a phosphorylated neurofilament epitope. J Neuropathol Exp Neurol 49:197-205.

Sasaki S, Maruyama S, Yamane K, Sakuma H, Takeishi M (1989) Swellings of proximal axons in a case of motor neuron disease. Ann Neurol 25:520-522.

Schmidt ML, Carden MJ, Lee VM, Trojanowski JQ (1987) Phosphate dependent and independent neurofilament epitopes in the axonal swellings of patients with motor neuron disease and controls. Lab Invest 56:282-294.

Sobue G, Hashizume Y, Yasuda T, Mukai E, Kumagai T, Mitsuma T, Trojanowski JQ (1990) Phosphorylated high molecular weight neurofilament protein in lower motor neurons in amyotrophic lateral sclerosis and other neurodegenerative diseases involving ventral horn cells. Acta Neuropathol (Berl) 79:402-408.

Sternberger LA, Sternberger NH (1983) Monoclonal antibodies distinguish phosphorylated and nonphosphorylated forms of neurofilaments in situ. Proc Natl Acad Sci USA 80:6126-6130.

Straube-West K, Loomis PA, Opal P, Goldman RD (1996) Alterations in neural intermediate filament organization: functional implications and the induction of pathological changes related to motor neuron disease. J Cell Sci 109:2319-2329.

Sun D, Leung CL, Liem RKH (1996) Phosphorylation of the high molecular weight neurofilament protein (NF- H) by $\mathrm{Cdk} 5$ and $\mathrm{p} 35$. J Biol Chem 271:14245-14251.

Thach WT, Goodkin HP, Keating JG (1992) The cerebellum and the adaptive coordination of movement. Annu Rev Neurosci 15:403-442.

Towbin H, Staehelin T, Gordon J (1979) Electrophoretic transfer of proteins from polyacrylamide gels to nitrocellulose sheets: procedure and some applications. Proc Natl Acad Sci USA 76:4350-4354.

Trojanowski JQ, Lee VM (1994) Phosphorylation of neuronal cytoskeletal proteins in Alzheimer's disease and Lewy body dementias. Ann NY Acad Sci 747:92-109.

Tu PH, Robinson KA, de Snoo F, Eyer J, Peterson A, Lee VM, Trojanowski JQ (1997) Selective degeneration of Purkinje cells with Lewy body-like inclusions in aged NFHLACZ transgenic mice. J Neurosci 17:1064-1074.

Vickers JC, Morrison JH, Friedrich Jr VL, Elder GA, Perl DP, Katz RN, Lazzarini RA (1994) Age-associated and cell-type-specific neurofibrillary pathology in transgenic mice expressing the human midsized neurofilament subunit. J Neurosci 14:5603-5612.

Wang E, Cairncross JG, Liem RK (1984) Identification of glial filament protein and vimentin in the same intermediate filament system in human glioma cells. Proc Natl Acad Sci USA 81:2102-2106.

Wong PC, Marszalek J, Crawford TO, Xu Z, Hsieh ST, Griffin JW, Cleveland DW (1995) Increasing neurofilament subunit NF-M expression reduces axonal NF-H, inhibits radial growth, and results in neurofilamentous accumulation in motor neurons. J Cell Biol 130:1413-1422.

Xu Z, Cork LC, Griffin JW, Cleveland DW (1993) Increased expression of neurofilament subunit NF-L produces morphological alterations that resemble the pathology of human motor neuron disease. Cell 73:23-33. 